\title{
IMPROVING WRITING SKILLS; AN IMPLEMENTATION OF "THINK PAIR SHARE" FOR ISLAMIC JUNIOR SCHOOLS STUDENTS
}

\author{
Suhrowardi \\ English Teacher, MTs Putra Al-Islahuddin Kediri, Indonesia \\ Corresponding Author Email: adi.lombokprabuwisata@gmail.com
}

\begin{tabular}{ll}
\hline \hline Article Info & Abstract \\
\hline Article History & The objectives of this study are to capture the implementation of Think Pair \\
Received: June 2020 & Share (TPS) in teaching-learning process, to identify the improvement of the \\
Revised: July 2020 & students' writing skills, and to find out the strengths and the weaknesses of Think \\
Published: July 2020 & Pair Share (TPS) in the teaching-learning process of the seventh-grade students \\
Keywords & of MTS AL Islahuddin Kediri. This research is a classroom action research. The \\
Writing skills; & interview and observation. The quantitative data was tested. The step to analyze \\
Think Pair Share; & the qualitative data used data reducing, data display, and conclusion drawing. \\
English Language & The step to analyze the quantitative data used mean formula. The result of the \\
Teaching; & research shows that there are positive improvements in either student" writing \\
& skills or the class situation during the teaching-learning process. It can be seen \\
from the result of the test which is improved, from the students" writing score \\
and the post-test conducted after the action. The mean scores of students" writing \\
scores are increased. Besides, the situation of the class is more conducive before \\
implementing it. From the class situations improvement, it can be drawn some \\
strengths and the weaknesses of the Think Pair Share (TPS) implementation in \\
writing class. The strengths include that the Think Pair Share (TPS) can build \\
critical thinking, motivation, classroom interaction, easy to discuss, -self- \\
confidence, and active learners. The weaknesses are required special attention in \\
classroom use, and it needs a mediator.
\end{tabular}

How to cite: Suhrowardi. (2020). Improving writing skills; an implementation of "think pair share" for Islamic junior schools students. JOLLT Journal of Languages and Language Teaching, 8(3), 287-296, DOI: https://doi.org/10.33394/jollt.v\%vi\%i.2751

\section{INTRODUCTION}

Writing is an important part of language teaching as it also has a function as an essential tool for learning in which students expand their knowledge of the language elements in reality (Xiao, 2007; Listyani, 2017; Haerazi \& Irawan, 2020; Qader \& Arslan, 2019). This skill must be explicitly taught because writing outside the school setting is relatively rare. Writing is also viewed as a social and cultural phenomenon as it is meaning-making that is socially and culturally shaped and individually and socially purposeful (Weigle, 2002; Haerazi et al., 2020). In this sense, writing falls into complexity and importance as well, but writing in English is a very complex process (Setyowati, Sukmawa, \& Latief, 2019). Writing is a highly sophisticated skill, combining a number of diverse elements that require not only grammatical but also a rhetorical element (Haerazi et al., 2018). So, we can say that the writing can be defined as an ability to communicate ideas through sign/written symbols by organizing the ideas based on the rules of language system to convey meaning so that readers can understand the writer "s messages.

MTS AL Islahuddin Kediri is one of school in Jirapan village. In every class, there are LCD, whiteboard, and teaching aids. MTS AL Islahuddin Kediriis located strategically. Based 
on the observation and interview in MTS AL Islahuddin Kediri of the seventh grade, writing is very low especially in the seventh. In addition, the students argue that learning writing is difficult and they feel afraid when they write in English. So, they are passive in the teachinglearning process. Therefore, the writing skill of the students of the seventh grade of MTS AL Islahuddin Kediri are still low, less than the criteria of the minimum requirement, in this case, the criterion of the minimum requirement of MTS AL Islahuddin Kediri is 70

The researcher found that the students have low competence in English. The main score was still low from passing grade. The average of students" writing score of the seventh D grade of MTS AL Islahuddin Kediri was 69, 31. It is indicated through the following indicators that are: (1) the students get difficulties in exploring an idea for their writing; (2) they get difficulties in grammatically correct sentences; (3) they get difficulties to produce various vocabulary to express language function in writing; (4) they felt that they could not write using English. While, from the situation, the indicators are: (1) the students make noise; (2) they do not participate in class; (3) they do not respond to the teacher commands; (4) the teaching and learning process is boring.

In fact, these problems come from the delivery of material and the techniques or methods used. The teacher dominates the classroom activities; it makes students passive during the teaching and learning process and makes their less interest. Sometimes, the teacher does not know the student "s need. Usually in the classroom, she only uses textbook or exercise book as the printed material to teach. It is boring and less innovative.

Based on some experiences in some schools, many people often get difficulties on there. In speaking February they get shy to speak because they fear getting wrong in producing some words? Then in writing they have no idea what they will write and they fears get wrong in grammar or they don "t know how to write, or they have lack of enough time to write. February be in the school when the teacher gives students an assignment to write a descriptive text, they feel bored because they are lazy to think and write many sentences. Then the last way, they use the internet to do their homework and spends an effective time and energy. The teacher is often confused about how to make their students creative in writing not copied other creation. They can make a descriptive text by themselves.

One way of teaching writing can be done, by think pair share strategy. Think pair share strategy here helped teachers in the teaching and learning the writing process. This strategy also helps students to improve their creativity in making a paragraph or essay. But here, the teacher is the main instructor to all of students' activity. The teachers are the main tutor here, and the main object is their students. This strategy has been ever done at some schools in Indonesia, such as in Surakarta, Boyolali. But this strategy used for other lessons, such as Biology, Mathematics

"Think-Pair-Share is a cooperative learning strategy that can promote and support higher-level thinking. The teacher asks the students to think about the specification of the topic. In pair, the students asked to discuss their own ideas and share their ideas with their group" From all of some activities in this strategy teacher hopes the students improve their skill, especially for writing. Although this strategy can help to solve these problems, the teacher should be active in the classroom than the students. Also, the teacher should be more creative.

The strategy above has been developed to present writing materials in the class. So, the students can make descriptive text more easily and full ideas. To find out better strategy, the researcher tried to have a study entitled "Improving student writing skill of descriptive text using think pair share of the VII Grade Students of MTS AL Islahuddin Kediri. To support this study, the researcher employs some theoretical views such as teaching writing skills and Think-Pair-Strategy views. 


\section{Teaching Writing Skills at Islamic Schools}

Teaching writing is a very important part of second language learning. Writing English is the main goal for many adult learners (Mali, 2017). Their personalities play a large role in determining how quickly and how correctly they will accomplish this goal. Those who are risk-takers unafraid of making mistakes will generally be more talkative, but with many errors that could become hard to break habits. Conservative, shy students take a long time to write confidently, but when they do, their English often contains fewer errors and they will be proud of their English ability. However, if the purpose of writing is communication and that does not require perfect English, then it makes sense to encourage quantity in your classroom. Break the silence and get students communicating with whatever English they can use, correct or not, and selectively address errors that block communication.

The mastery of writing skills in English is a priority for many second language learners or foreign-language learners often evaluate their success in language learning as well as the effectiveness of their English course on the basis of how much they feel they have improved in their written text proficiency. Hand skill has hardly been neglected in EFL/ESL courses, though how best to approach the teaching of hand skill has long been the focus of methodological writing text descriptive. Teachers can use various approaches ranging from the direct approaches focusing on specific features of writing interaction such as turn-taking, topic management, and questioning strategies. For instance, the indirect approaches is able to create conditions for a writing interaction through group work, and task work (Richards, 1990).

Based on the Kurikulum k-13 for SMP and MTs, the program of teaching-learning English as a foreign language focuses on the aims to develop students" skill in four language skills. The students are expected to achieve competencies to communicate with the writing English well. Outside the context of any classroom, all children who are repeatedly exposed to language, in normal circumstances, will learn it unconsciously. Most adults can learn a language without studying it. Though they February have more trouble with pronunciation and grammar than younger learners, they February still be able to communicate fluently.

In teaching writing, the teacher mostly emphasizes his/her teaching product of writing. It means that the teachers occasionally practice the teaching of writing, started by only explaining the topic the students are going to speak about while the students read to the explanation no model is provided to the students as the example. The students are asked to write and read short dialogue or composition in a certain time allotted without practice to write or to produce what they have learned before.

\section{Think-Pair-Strategy}

Think-Pair-Share is a strategy designed to provide students with "food for thought" on a given topic enabling them to formulate individual ideas and share these ideas with another student. It is a learning strategy developed by Lyman and associates (2001) to encourage student classroom participation. Rather than using a basic recitation method in which a teacher poses a question and one student offers a response, Think-Pair-Share encourages a high degree of pupil response and can help keep students on task.

Think pair share is a cooperative discussion strategy developed by Frank Lyman in his colleagues in Maryland. They get its name from the three stages of student "s action, with emphasis on what students are to be doing at each of those stages. (1) Think, the teacher asked the students" thinking with a question or prompt or observation. The students should take a few moments, probably not minutes, just to think about the question or topics. (2) Pair, using designated partners nearby neighbors or a deskmate, student "s pair up to talk about the answer each came up with. They compare their mental or written notes and identify the answers they think are best, most convincing, or most unique. (3) Share, after students talk in 
pairs for a few moments (again, usually not minutes), the teacher calls for pairs or individually to present their thinking with the rest of the class" (Fahlefi, 2010)).

Think, pair, share strategy is a cooperative learning_technique that encourages individual participation and is applicable across all grade levels and class sizes (Nunan, 1998) students think through questions using three distinct steps": Think: Students think independently about the question that has been posed, forming ideas of their own. Pair: Students are grouped in pairs to discuss their thoughts. This step allows students to articulate their ideas and to consider those of others. Share: Student pairs share their ideas with a larger group, such as the whole class. Often, students are more comfortable presenting ideas to a group with the support of a partner. In addition, students' ideas have become more refined through this threestep process.

Think-Pair-Share is a cooperative learning strategy that can promote and support higherlevel thinking. The teacher asks the students to think about the specification of the topic, pair with another student to discuss their thinking, and then share their ideas with the group" (Lyman, 1981). Think, Pair, Share is a structure first developed by Professor Frank Lyman at the University of Maryland in 1981 and adopted by many writers in the field of cooperative learning since then. It introduces into the peer interaction element of cooperative learning the idea of "wait or think" time, which has been demonstrated to be a powerful factor in improving student responses to questions. It is a simple strategy, effective from early childhood through all subsequent phases of education to tertiary and beyond. It is a very versatile structure, which has been adapted and used, in an endless number of ways. This is one of the foundation stones for the development of the cooperative classroom.

\section{RESEARCH METHOD Research Design}

The method used in this study is classroom action research. There are some definitions of action research proposed by experts. Carr and Kemmis (1982) in Burns (1999:30) states that action research is simply a form of self- reflective inquiry undertaken by participants in a social situation to improve the rationality and justice of their own practices, their understanding of this practices and the situations in which the practices are carried out. According to Burn (2000) action research is a systematic inquiry conducted by teachers, researchers, principals, school counselors, or other stakeholders in teaching or learning environment. It aims to gather information about the ways that their particular schools operate, how they teach, and how well their students learn. This information is gathered with the goals of gaining insight, developing reflective practice, effecting positive changes in the school environment (and on educational practices in general), and improving students' outcomes and the lives of those involved. Figure 1 shows the steps of action research. 


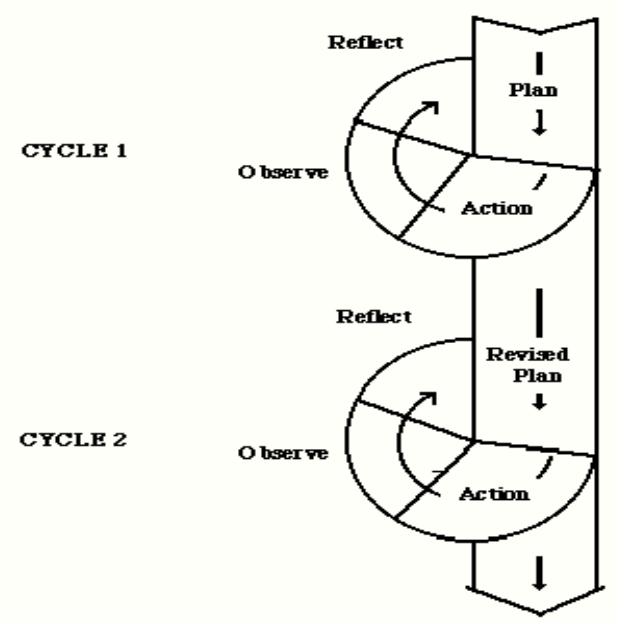

Figure 1. The Concept of Action Research Based on Kemmis and Mc. Taggart

\section{Subject of the Study}

The subject of this research is the seventh D grade of MTS AL Islahuddin Kediri. The class consists of 36 students. There are 19 boys and 17 girls in the class of seventh D. The researcher did the research to the seventh $\mathrm{D}$ grade based on a lack of student writing skills. Based on the result of the interview with the teacher and students, the researcher obtained information that the students of the seventh D class had lower writing skills than other classes. According to the English teacher, the students of this the seventh D class have some problems in writing activity, they are: the students" lack of vocabulary, the students" lack of grammar mistakes in writing English, the students" low motivation in writing activity, the students' in confidence in performing writing and the students felt cannot write English. In addition, the students are lack of paying attention when the teacher teaches them. Therefore, the writing score for this class is not good.

\section{Technique of Collecting Data}

It is very important to collect the data in research because the data are used to get the result of the research. In this classroom action research, the techniques of collecting the data used by the teacher are observation and test. The interview was done to get information from the students and the teacher about all of the activities was done along as the teaching-learning process and to explore the information. Through this activity, the observer would help to collect the information from the students and the teacher easily. The researcher interviewed the teacher and the students about the way she implemented the material, and the problem faced. The researcher also interviewed the students about their responses to learning writing skills through small group discussions. The researcher did the interview before and after conducting research in order to know the teachers' view of the teaching process and students writing skills. The average of students" writing score was 69, 31., in MTS AL Islahuddin Kediri the criteria of a minimum requirement is 72,12 .

The writer gave a pre-test in order to measure students' achievement in learning the material. The writer gave the pre-test to the students before implementing the action. They did the pre-test based on the method of their real English teacher. The test is describing things in the classroom. The writer gives the students test to describing something or object around class, first the writer gives the students question. After that, the students will describe the question. After the students finish do the question, the writer gives the score which the average 70, 42 from the criteria minimum requirement 72, 12. After implementing the action, the writer gave the post-test to them. The students were instructed to write with several 
guidelines. The material in the first post-test in cycle 1 was descriptive text. The media used in cycle 1 was text descriptive. The material in the second post-test in cycle 2 was descriptive text, and the media used was pictures.

\section{Data Analysis}

In the process of analyzing the data, the researcher categorized the data into two kinds of data are qualitative data and quantitative data. Qualitative data was to analyze the data of observation and interview. According to Miles and Huberman (2011), there are three steps of analyzing data. Reduce the data is summarizing, choosing, and focusing on the main data. There are many data that have been collected during the research. Besides that, the researcher needs to reduce the data for analyzing the data. It makes it easier for the researcher to find the data that she needs. The data that is needed by the researcher had been collected after doing the research. The researcher reduced the syllabus and English score in the seventh grade of MTS AL Islahuddin Kediri. After reducing the data, the next step is displaying the data. Displaying the data helps the researcher to understand what is happening and to do some things further analysis on that understanding. The first, the researcher took a syllabus that was related to speaking skill, and the second, the researcher took the data in English score just in writing skill. The last step is drawing a conclusion from the data of displaying processes.

\section{RESEARCH FINDINGS AND DISCUSSION Research Findings}

This section consists of two sub-sections: cycle 1 and cycle 2 , each sub-section is elaborated in four steps (planning, acting, observing, and reflecting). The researcher did cycle 1 in two meetings at $13^{\text {th }}$ January 2020 , and $14^{\text {th }}$ January 2020. Cycle 2 was also done in two meetings at $7^{\text {th }}$ February 2020 and $8^{\text {th }}$ March 2020.

Cycle 1

This cycle was conducted on Monday, $13^{\text {th }}$ January 2020 , and Tuesday, $14^{\text {th }}$ January 2020 with a time allocation of $2 \times 40$ minutes. The result of the implementation of the four steps in Cycle 1 is as follows:

\section{Planning}

Before implementing the TPS method in teaching writing in class, the researcher made some preparations. The preparation is in the form of lesson plans containing the instructional objectives, instructional material and media, the teaching-learning activities, and the evaluation. The instructional material of that day was the descriptive text by using TPS method. He took the method in students' "writing process.

\section{Implementation}

Meeting 1

At the beginning of the class, the teacher greeted checked the students' attendance and gave motivation to the students. Then the teacher explained the material of that day to the students. After explaining the material of that day, the teacher explained about TPS method. Then the teacher prepared them for writing. Next, the teacher explained to the student about the way to use the TPS method in writing descriptive text. After that, she divided the students into several groups and gave the topic to discuss. And then, she allowed the students to ask some questions if they have any difficulties in the material. Finally, she asked students to write a descriptive text using the TPS method.

\section{Meeting 2}

At the second meeting, the teacher gave a post-test to the students. First, at the beginning of the class, the teacher greeted, checked students" attendance, and gave motivation to the students and reviewing material for 10 minutes. The teacher gave the opportunity to ask 
if the students got difficulties in understanding material and the way to use the TPS method which helps them in writing. Next, she gave a post-test and she asked them to make an outline from the theme. Next, she asked them to write a descriptive text by using an outline. The students did and finished. Finally, she asked the students to submit their work and closed the meeting.

\section{Observation}

The observation was done by the researcher during the implementation of the TPS method. The collaborator wrote down the problem that happened during a teaching learning activity. The result of the observation showed that the researcher had implemented every step as it was described in the lesson plan. However, there are some problems that happen in core activities. First, some of the students did not understand teacher explanation so the students confused to make a descriptive text. Second, some students did not want to ask about the material that the teacher explanation so they get difficulties in grammar, spelling and mechanics, and the students did not respond to the teacher's explanations about the material, so they can not do the task as well.

\section{Reflection}

Reflecting the final phase of cycle 1 consisted of the evaluation of the process and the students' results. In general, it can be summed up that the TPS method in cycle 1 had not met the success yet, although the students" writing was improved. There were many problems occurring during the implementation of the strategy, so its result could not be achieved naturally. First, the students were confused about how to do descriptive writing. Second, in the post-test some students did not participate in writing the text. In this meeting result of the post-test in cycle 1 showed that 12 students got 70-90 (47,9\%), 12 students got 50-69 $(30,4 \%), 10$ students got less 50 (13\%), 2 students did not participate $(8,7 \%)$. Based on the result of the post-test conducted in cycle 1, it was found out that the mean score of the students" writing test was 56,20. The mean score of 58,7 indicated that there was not an improvement of the students" writing if compared with the mean score of 70 from the criteria of success. Therefore, the next cycle was still needed to conduct, and some revisions of cycle 1 were also made to improve the students' writing.

From the problem occurring in the implementation of the TPS method in writing descriptive text, the researcher made some revisions on the lesson plan and the collaborator teachers' way of carrying out the strategy of using this method. In terms of revision on the lesson plan, she revised the TPS method used for the next cycle. This research used the TPS method in a different theme which was close to the student environment. In terms of the strategy, she discussed with the collaborator teacher about the way in explaining the students to use the TPS method in the writing process. The finding was the collaborator teacher explained the way to use the TPS method to the students slowly. She also gave students clearer instructions asking the students to made descriptive text. The researcher gave the students more guidance, help, and encouragement during the implementation of the method. In the revision process of writing, the students exchange their work with their classmates to be revised.

\section{Cycle 2}

Research finding in cycle 2 was conducted on February, $7^{\text {th }} 2020$, and February, $8^{\text {th }}$ 2020. In every meeting, the time allocation is $2 \times 40$ minutes. The implementation of the four steps were run well. Based on the students'" learning result, it showed that the students had improved their idea in writing because they can write long paragraphs than before so, there was an improvement that can be examined from the criteria defined in this study. The scores this of the test were higher than the score of the test in cycle 1.27 students got least $70(87 \%)$, and 9 students less than $70(13, \%)$. It means that the criteria of success had been achieved in 
which the students" mean score should be at least 70 . The mean score of the students" writing improved from 56,20 in cycle 1 to 71,77 in cycle 2 . It means that the criteria of success defined in the study had been achieved. The number of students who made improvements on their score in writing was increased from 11 students or $47,9 \%$ to 20 students or $87 \%$ in cycle 2. Thus, the criterion has been reached in writing descriptive text by using the TPS method.

\section{Discussion}

TPS is a strategy designed to provide students with "food for thought" on a given topic enabling them to formulate individual ideas and share these ideas with another student. In this study, TPS is to help the students improving their idea in writing descriptive text. It requires the teacher to follow a particular procedure. 1) the teacher gives the goal of the study and motivates the students before explaining the material. 2) the teacher explains about TPS method and descriptive text. 3) the teacher asked about the descriptive text. 4) students discuss the material with their partners. 5) the teacher calls for pairs or individually to present the material with the rest of the class. It is in line with what Sumekto (2019) applies in the reading classes. Furthermore, the findings show the think-pair-share strategy is able to develop students' thinking skills and ideas.

First, the goal of study and motivation was really very beneficial because the students would be motivated and had a spirit in the teaching-learning process, so the students become active in the lesson (Eazhull, 2003). Thus, students can be interested in lessons. Second, the teacher began to explain the TPS method and descriptive text to give the student understanding of the material and the strategy. In addition, students are provided feedback to see their previous performance. It is in accordance with Aydawati et al. (2019) who state feedback in writing is essential for students. Because of this, students would be more understanding of the material to be provided. Third, the teacher divided the students into several groups. It is the same result shown by Prayati (2019) who conducts a study in which group works can help students to accomplish their writing easily. For students who lack academic ability in a group means that there are friends who can help, while the students' good academic ability can further enhance their capabilities. So the group can improve the academic quality of students. Fourth, the students discuss the material with their partners to increase their knowledge. Discussion can increase student participation and activities in the lesson by giving students the chance to voice their opinions, help students to develop a better understanding by providing an opportunity to express their thoughts, and help students to improve their communication skills (Suryosubroto, 2009).

Finally, the students show the results of their discussions. With the students show their discussions, they will know where their deficiencies so that they can revise it. The TPS was effective in improving students' ideas in writing descriptive text. It is in accordance with Bohari (2019) who finds that a piece of discussion in the class can help students to think what they are going to write. Although the method easy and simple to use, the researcher needs to have a collaborator teacher to help in teaching by using Think Pair Share strategy. It helped the researcher to focus on teaching in the class. It is a simple strategy, effective from early childhood through all subsequent phases of education to tertiary and beyond. It is a very versatile structure, which has been adapted and used, in an endless number of ways. This is one of the foundation stone for the development of the cooperative classroom.

Think, Pair, Share helps students develop a conceptual understanding of a topic, develop the ability to filter information and draw conclusions, and develop the ability to consider other points of view. And then the Think Pair Share can make the quite student to be active to discuss with another friend in a group. The smart students and help the quit e students to get understanding the material from the teacher. With the discussion in a group, the teacher can see students active to think and not active to think. But the teacher must correctly know about 
the student in a group because there are the students just joint in the group not think together with the group. The Think Pair Share technique also can make the students lazy to think individuals because they are just joint in the group.

\section{CONCLUSION}

Based on the students' scores in the preliminary study, it is known that the students" achievement was needed to be improved since their scores were low. They were low in improving their idea in writing, to improve them the students should be supported by a strategy. The students' "mean score improved from 56,8 in a preliminary study to 58,7 in Cycle 1 and it could 73,69 in Cycle 2. In Cycle 2 the teacher using any procedures. 1) the teacher gives the goal of the study and motivates the students before explaining the material. 2) the teacher explains about TPS method and descriptive text. 3) the teacher asked about the descriptive text. 4) students discuss the material with their partners. 5) the teacher calls for pairs or individually to present the material with the rest of the class.

The writer found another increase in the students who passed the test in the second cycle. The result of the study in this cycle was satisfactory most of the students" score passed in the test. The pairs or groups can enhance the knowledge of students because they can exchange opinions and knowledge more of them. So, TPS helps students develop a conceptual understanding of a topic, develop the ability to filter information and draw conclusions, and develop the ability to consider other points of view.

\section{ACKNOWLEDGEMENT}

The researcher realizes that this thesis cannot complete without any helps from others. Thus, the researcher wishes to express the special gratitude to those who contribute to any part of this manuscript. All of the lecturers and official employees of Islamic Education and Teacher Training Faculty. Thanks for giving the service and time during this study. In addition, I also thank the Headmaster and English teacher of MTS AL Islahuddin Kediri for giving permission and patience to help the researcher in doing this study.

\section{REFERENCES}

Analia ika, Isdiyah. 2012. Using Think Pair Share (TPS)to Improve the Descriptive Writing Skill of the VII Grade Student of MTs Darusalam Aryojeding

Arends, R.I. (2004). Learning to Teach (Seventh Edition). New York: McGraw- Hill Companies

Aydawati, E. N., Rukmini, D., Bharati, D. A. L., \& Fitriati, S. W. (2018). The Correlation between Online Peer Review and Academic Writing Students' Learning Styles. Celt: A Journal of Culture, English Language Teaching \& Literature, 18(2), 239. https://doi.org/10.24167/celt.v18i1.1246

Bohari, L. (2019). Improving speaking skills through small group discussion at eleventh grade students of SMA Plus Munirul Arifin NW Praya. Journal of Languages and Language Teaching, 7(1), 68-81. doi: https://doi.org/10.33394/jollt.v7i1.1441

Brown, H. D. (2001). Teaching by Principles an Interactive Approach to Language Pedagogy (Second Edition). New Jersey: Addison Wesley Longman Inc

Burns, A. (2009). Doing Action Research in English Language Teaching: a guide for practitioners. New York: Routledge

Fauziati, E. (2011). Teaching of English as Foreign Language. Surakarta: Muhammadiyah University Pers. 
Haerazi, H., \& Irawan, L. A. (2020). Developing Intercultural Language Learning (ILL) model to teach writing skills at Indonesian private universities. EduLite: Journal of English Education, Literature and Culture, 5(1), 43. https://doi.org/10.30659/e.5.1.43$\underline{54}$

Haerazi, H., Irawan, L. A., Suadiyatno, T., \& Hidayatullah, H. (2020). Triggering preservice teachers' writing skills through genre-based instructional model viewed from creativity. International Journal of Evaluation and Research in Education, 9(1), 234-244. https://doi.org/10.11591/ijere.v9i1.203945

Haerazi; Irwansyah, Dedi; Juanda; Azis, Y. A. (2018). Incorporating Intercultural Competences in Developing English Materials for Writing Classes. Journal of Language Teaching and Research, 9(3), 540-547. https://doi.org/http://dx.doi.org/10.17507/jltr.0903.13

Listyani, L. (2017). Academic Writing Students' Affective Reactions towards Joint Reconstruction Phase of Reading to Learn. Celt: A Journal of Culture, English Language Teaching \& Literature, 17(2), 251. https://doi.org/10.24167/celt.v17i2.1206

Louma, S. (2004). Assessing Writing. Cambridge: Cambridge University Press Mills, Geoffrey E. et al 1995. Educational Research. New Jersey: Pearson Prentice Hall.

Mali, Y. C. G. (2017). Motivational Teaching Strategies in Indonesian EFL Writing Classrooms. Celt: A Journal of Culture, English Language Teaching \& Literature, 17(1), 60. https://doi.org/10.24167/celt.v17i1.1139

Nunan, D. (1992). Research Methods in Language Learning. UK: Cambridge University Press

Nunan, D. (1998). The Learner-Centred Curriculum. A Study in Second Language Teaching. Gread Britain: Cambridge University Press.

Prayati, Z. (2019). The effect of team product to improve students' creativity in writing at SMPN 1 Jonggat. Journal of Languages and Language Teaching, 8(1), 40-47. doi: https://doi.org/10.33394/jollt.v8i1.2213

Qader, R. O., \& Arslan, F. Y. (2019). The effect of flipped classroom instruction in writing: A case study with Iraqi Efl learners. Teaching English with Technology, 19(1), 36-55.

Rahmawati, D. (2013). Improving Students' Writing Skill for Descriptive Text Using Media (A Classroom Action Research to the $8^{\text {th }} F$ Students of Junior High School in MTs Jatinom at Klaten in Academic Year 2011/2012) Thesis. Surakarta: IAIN Surakarta.

Setyowati, L., Sukmawa, S., \& Latief, M. A. (2017). Solving the Students' Problems in Writing Argumentative Essay Through the Provision of Planning. Celt: A Journal of Culture, English Language Teaching \& Literature, 17(1), 86. https://doi.org/10.24167/celt.v17i1.1140

Sugiyono. (2011). Metode Penelitian Kualitatif Kuantitatif dan R\&D. Bandung: Alfabeta

Sumekto, D. R. (2018). Investigating the Influence of Think-Pair-Share Approach toward

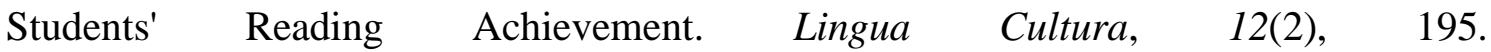
https://doi.org/10.21512/lc.v12i2.4011

Xiao, Y. (2007). Applying metacognition in EFL writing instruction in China. Reflections on English Language Teaching, 6(1), 19-33. http://www.nus.edu.sg/celc/publications/RELT61/p19to34xiao.pdf 